\title{
DISCOVERING PHONEMES OF BIDAYUH
}

\author{
Jecky Misieng \\ Centre for Language Studies, Universiti Malaysia Sarawak \\ mjecky@cls.unimas.my
}

\begin{abstract}
There are generally three views of the notion of a phoneme. The structuralist view of the phoneme focuses on this language phenomenon as a phonetic reality. In discovering phonemes of a language, phonologists who hold this view will look for minimal contrasting pairs as a way to determine contrasting sounds of that language. They will also look for allophones or two sounds of the same phoneme which may appear in complementary distribution. This paper will discuss the possible application of the structuralist approach to analyzing the phonemes of a dialect of Bidayuh, one of the Malayo-Polynesian languages spoken in the northern region of Borneo.
\end{abstract}

Keywords: Bidayuh, structuralist-approach, phonemic analysis

\section{Introduction}

Human languages employ sound as the basis for oral communication. Each language has a set of distinct sounds to produce utterances that carry meaning. According to Hyman (1975), this language phenomenon is called a phoneme and it is defined as a minimal unit of sound capable of distinguishing words with different meanings. However, there are conflicting views among phonologists as to the nature of a phoneme, three of which will be explained here. The first view is held by the American Structuralists who define the phoneme as a physical reality (Jones, 1967) and they focus their observation on the phonetic form. The second view is that a phoneme is a minimal unit that can function to distinguish meanings and this notion was first introduced by the Prague School. Unlike the Structuralist view, the Prague School phonologists consider phoneme a phonological reality (Trubetzkoy, 1969) which implies that it is nothing more than an abstraction. The last view which was led by Badouin de Courtenay from the Kazan School of Linguists, defined the phoneme as a psychological reality (de Courtenay, 1972). According to this view, when a speaker pronounces a word, phonetically, his or her real intention or abstract image is the phoneme (Anderson, 1985). Despite the ongoing disputes among phonologists regarding the nature of the phoneme (e.g., Twaddel, 1935), this article will attempt to analyse the Bidayuh phonemes using the Structuralist approach.

\section{A Structuralist Approach to Discovering Phonemes}

The following is a description of how phonologists who hold the structuralist point of view try to discover a phoneme of a given language. There are four steps involved in discovering phonemes: (1) collect and record a representative sample of the language under investigation; (2) set up minimal contrasting pairs; (3) ascertain complementary distributions; and (4) assign allophones to their appropriate phonemes. 
The first step in analyzing the phonemes is to collect a representative corpus of items of the language under study. A reliable transcription of the phonetic detail along with glosses for the items is necessary for analysis. In order to do this, the International Phonetic Alphabet (IPA) is recommended (International Phonetic Association, 1999).

The next step is to set up an inventory of the sounds of suspicious pairs from the corpus. These sets of suspicious pairs should then be listed to assist in investigating contrast and complementary distribution. Contrast refers to the fact that different phonemes have the capability of distinguishing the words of a language from another (Wolfram \& Johnson, 1982). The contrast can be determined by looking at pairs of words that differ by just one phoneme. Using minimal contrasting pairs, the basic phonemic contrast in identical environment of a language system can be determined. Near-minimal word pairs or pairs of words that contrast in an analogous environment can be employed if no minimal word pairs are available.

Complementary distribution, on the other hand, refers to the phonetic realizations of a single phoneme that cannot contrast with each other, that is, when one of the sounds is realized in one environment, the other will be in a different environment. These two sounds are called allophones. They are two phones or sounds of the same phoneme. After completing the above step, the next step is to formulate a hypothesis (or hypotheses) on the complementary distribution of sounds which might be allophones of the same phoneme. The hypothesis is tested by applying it to the corpus.

The final step in phonemic analysis using the Structuralist approach is to look for variants among the suspicious pairs and assign them as allophones to whichever phoneme they belong to. These are the remaining phones in the corpus that do not distinguish word meanings. The realization of these allophones in spoken language can be predicted by phonological rules.

The final outcome of any phonemic analysis is to put together an accurate and a fully representative sample of the sound patterns of the language under investigation. To carry this out, a phonetic chart for consonants and vowels based on the IPA has to be drawn. It is also useful to include a chart for diacritics (i.e. small symbols that are added to the regular IPA symbols) to denote very specific descriptions of the sound, so that an accurate and a more detailed account can be obtained and interpreted.

\section{Phonemic Analyses}

One of the most important uses of phonological analysis involves orthography, that is, the use of an alphabet to represent a language in writing (Wolfram \& Johnson, 1982). Countries such as Malaysia and Indonesia have adopted the Roman alphabet to develop a standardized writing system due to the similarity of Malay spoken in the two countries. Bahasa Malaysia and Bahasa Indonesia are two varieties of the Malayo-Polynesian languages found in South-east Asia. Politically, there are two different Malay languages but in the linguistic sense, they are varieties or dialects of the same language. Although BM and BI share many similarities in pronunciation, they have different writing systems. This is mainly because Malaysia and Indonesia inherited a different spelling system from their respective colonial masters. Bahasa Malaysia was influenced by the British spelling system while Bahasa Indonesia was influenced by the Dutch spelling system. For example, the way that the palato-alveolar affricates were written in Bahasa Malaysia appeared differently in Bahasa Indonesia. The voiceless affricate[ $\mathrm{t}]$ in the Bahasa Malaysia word "chinta" (love) is indicated 
by the letters "ch" whereas the voiced affricate [ $[\xi]$ in the word "janji" (promise) is represented by the letter " $\mathrm{j}$ " (Table 1).

Table 1

Representations of the voiceless affricate in Bahasa Malaysia

\begin{tabular}{lll}
\hline \multicolumn{1}{c}{ Item } & Phonetic Detail & Gloss \\
\hline chinta & /t Inta/ & love \\
janji & $/$ dzandzI/ & promise \\
\hline
\end{tabular}

Bahasa Indonesia, on the other hand, has the voiceless affricate as $[\mathrm{t}]$ and $[\mathrm{d}]$ respectively. Incidentally, the Bahasa Indonesian versions of the words closely resemble that of the IPA (Table 2).

Table 2

Representations of the voiceless affricate in Bahasa Indonesia

\begin{tabular}{lll}
\hline Item & Phonetic Detail & Gloss \\
\hline tjinta & /t Inta/ & love \\
djandji & /dzandzI/ & promise \\
& \\
\hline
\end{tabular}

Realizing that these words are pronounced similarly in Bahasa Malaysia and Bahasa Indonesia, both countries agreed to use the orthographic symbol of " $\mathrm{c}$ " for the voiceless affricate and " $\mathrm{j}$ " for the voiced counterpart. Therefore, the new spellings for the two examples above are "cinta" and "janji".

Uses of phonemic analysis can also be extended to create a writing system for languages that have no standardized written form. A good example is the Bidayuh language ( $\mathrm{Ng}$, Chin, Yeo \& Ranaivo-Malançon, 2010), another variety of the Malayo-Polynesian languages. Attempts have been made to write the Bidayuh language using the Roman Alphabet. A Bidayuh-English dictionary is now available called the "Daya Bidayuh-English" dictionary (William, 1988). The dictionary is confined to words from one Bidayuh dialect. Most of the major developments in recent research about the language were achieved through the Bidayuh Language Development Project (Rensch, Rensch, Jonas, \& Robert, 2006). Rensch et al. have studied 25 dialects of Bidayuh and provided phonological descriptions of the dialects, particularly the occurrences and roles of nasality. Apart from this, there have been relatively few attempts at capturing the sound of the language in writing. The next section provides a phonemic analysis of the Bidayuh language to illustrate the difficulty of representing glottal stops in the Bau-Jagoi dialect.

\section{Phonemic Analyses of Bidayuh Language: A Case of Bau Jagoi}

The overarching problem that hinders an accurate writing system of Bidayuh is assigning the Roman Alphabet to the sounds of the language that can accurately portray the way they 
should be pronounced. Different letters have been used to symbolize the same sound even in instances of recording the same dialect, resulting in the same words appearing in many different spellings. This is very confusing for those who wish to use the existing BidayuhEnglish dictionaries as a basis for doing research on the Bidayuh language.

In the Bau-Jagoi dialect, for instance, there is no agreement as to the correct spelling for words with a glottal stop $/ R /$. According to Ladefoged and Maddieson (1996), the glottal stop is produced by putting the two vocal folds tightly shut momentarily as to stop all air from flowing out and then releasing it suddenly. This particular sound is found to be a phoneme in most dialects of Bidayuh (Rensch et al., 2006). Glottal stops that appear in the final position of words have been variously represented by " $h$ " and " $k$ ". Some writers do not use any letter to indicate the glottal stop because there are no symbols in the Roman writing system that can be used for this purpose (e.g., William, 1988). Table 3 shows three examples to illustrate the point.

Table 3

Representation of glottal stops for Bau-Jagoi dialect of Bidayuh

\begin{tabular}{lccc}
\hline Item & $\begin{array}{l}\text { Glottal stops } \\
\text { represented by the } \\
\text { letter ' } \mathbf{h} \text { ' }\end{array}$ & $\begin{array}{l}\text { Glottal stops } \\
\text { represented by the } \\
\text { letter ' } \mathbf{k} \text { ' }\end{array}$ & $\begin{array}{l}\text { Glottal stops are not } \\
\text { represented by any } \\
\text { alphabet letters }\end{array}$ \\
\hline insane & bakoh & bakok & bako \\
Knife & sindah & sindak & sinda \\
People & dayah & dayak & daya \\
\hline
\end{tabular}

My contention is that all the above are inaccurate because they lead to incorrect pronunciation and, at times, bring different meaning than is intended and understood by Bau-Jagoi speakers. A speaker of Bidayuh knows that pronouncing words shown in Table 3 with the $/ \mathrm{h} /$ and $/ \mathrm{k} /$ sound or even omitting the glottal stop altogether is inaccurate. The resulting words may not correspond to any existing words in the Bidayuh lexicon and even if it does, it would have a different meaning than is originally intended.

This is because the glottal stop is not just an allophone to a phoneme but phonemic in the Bau-Jagoi dialect of Bidayuh because it changes the meaning as shown by the minimal contrastive pairs both in middle and final positions of words. Thus, as a compromise, I would adopt the convention used by a number of writers of Bidayuh language (e.g., Dundon, 1989) who use the symbol ' (apostrophe) to indicate glottal stops. Dundon, however, only recognizes the glottal stop when it appears in the middle position (e.g. "bo'os" for sleep) but not in the final position ("sama" for father). Incidentally, if the word "sama" is pronounced the way it is spelt, it is not a Bidayuh word for father in the Bau-Jagoi dialect.

In the Bau-Jagoi dialect of Bidayuh. * $d$ is almost always an implosive $/ d /$ when it is in the middle and final positions of words. Table 4 shows that when the glottal stop in the middle position of the word is not indicated by an apostrophe (e.g., baat), this could lead to a different pronunciation and eventually a different meaning than originally intended. 
Table 4

Glottal stop for implosive /d/ in the middle position of Bau-Jagoi words

\begin{tabular}{|c|c|c|c|c|c|}
\hline \multicolumn{2}{|c|}{$\begin{array}{l}\text { Glottal stop is indicated } \\
\text { by an apostrophe }\end{array}$} & \multirow[b]{2}{*}{ Meaning } & \multicolumn{2}{|c|}{$\begin{array}{l}\text { Glottal stop is not } \\
\text { indicated by an } \\
\text { apostrophe }\end{array}$} & \multirow{2}{*}{$\begin{array}{l}\text { A different } \\
\text { meaning than } \\
\text { originally } \\
\text { intended }\end{array}$} \\
\hline Item & $\begin{array}{l}\text { Phonetic } \\
\text { detail }\end{array}$ & & Item & $\begin{array}{l}\text { Phonetic } \\
\text { detail }\end{array}$ & \\
\hline ba'at & /ba?at/ & heavy & baat & /ba:t/ & a boundary \\
\hline ma'ad* & /m?ad/ & $\begin{array}{l}\text { To go up or go } \\
\text { home }\end{array}$ & mad* & /mad/ & $\begin{array}{l}\text { to put on the } \\
\text { ground }\end{array}$ \\
\hline pi'in & /pI?In/ & water & pin & /pin/ & $\begin{array}{l}\text { a pin (borrowed } \\
\text { from English) }\end{array}$ \\
\hline
\end{tabular}

Table 5 shows that the use of apostrophe to indicate a glottal stop in the final position of Bau-Jagoi words for the other two voiced plosives $/ 6 /$ and $/ g /$ will ensure that the intended meaning is conveyed. For example, "bako" means crazy whereas "bako" refers to the name of a tree.

Table 5

Glottal stop for voiced plosives $/ 6 /$ and $/ g /$ in final position of Bau-Jagoi words

\begin{tabular}{|c|c|c|c|c|c|}
\hline \multicolumn{2}{|c|}{$\begin{array}{l}\text { Glottal stop is } \\
\text { indicated by an } \\
\text { apostrophe }\end{array}$} & \multirow{2}{*}{ Meaning } & \multicolumn{2}{|c|}{$\begin{array}{l}\text { Glottal stop is not } \\
\text { indicated by an } \\
\text { apostrophe }\end{array}$} & \multirow{2}{*}{$\begin{array}{c}\text { A different } \\
\text { meaning than } \\
\text { originally intended }\end{array}$} \\
\hline Item & $\begin{array}{l}\text { Phonetic } \\
\text { detail }\end{array}$ & & Item & $\begin{array}{l}\text { Phonetic } \\
\text { detail }\end{array}$ & \\
\hline bako' & /bakJ?/ & crazy & bako & /bakJ/ & name of a tree \\
\hline sinda' & /sInda?/ & a knife & sinda & /sInda/ & to talk \\
\hline tula' & /tUra?/ & a fly & tulak & /tひrak/ & to push \\
\hline bula' & / bUra?/ & to lie & bulah & /bUrah/ & to open eyes \\
\hline sama' & /sama?/ & father & samah & /samah/ & the same \\
\hline daya' & /daja?/ & people & daya & /daja/ & $\begin{array}{l}\text { an effort } \\
\text { (borrowed from } \\
\text { Malay) }\end{array}$ \\
\hline
\end{tabular}

Taking this further, the Daya Bidayuh-English dictionary should be renamed as the "Daya' Bidayuh-english dictionary" for greater accuracy in pronunciation.

There are other sounds of Bau-Jagoi Bidayuh which have yet to be investigated such as the voiced implosives mentioned above. Native speakers know that articulating a word without using the implosives would make a person sound like a non-native speaker. Other sounds in Bau-Jagoi words to be considered for analysis are combinations of nasals and stop 
consonants. For example, the word "manuk" is actually pronounced as /manduk/ by BauJagoi speakers. Another example is "ma" (don't) which is pronounced as /mba?/. These nasals are also often accompanied by a sound similar to a voiceless plosive at the end of words. Examples such as the bilabial nasal $/ \mathrm{m} /$ and voiceless bilabial plosive $/ \mathrm{p} /$ in words like "kuwuom" /kuwuomp/ (sinking). Likewise, the alveolar nasal and the alveolar plosive in words such as "boton" /botont/ (eye) and the velar nasal and the velar plosive in words such as "tukang" /tひkank/ (expert).

With the knowledge of what constitutes a phoneme and how to discover it as exemplified using the Structuralist method of analyzing phonemes, a more effective and accurate convention for writing the Bau-Jagoi dialect in particular, and the Bidayuh language in general, is feasible. It would also be useful to have in the linguist inventory a method to investigate suspicious sounds mentioned above so that an accurate wordlist of the dialect could then be obtained.

\section{References}

Anderson, S. R. (1985). Phonology in the twentieth century: Theories of rules and theories of representations. Chicago: Chicago University Press.

de Courtenay, B. (1972). Some general remarks on linguistics and language (1871). Translated from Russian In E. Stankiewicz (ed.), Selected Writings of Baudouin de Courtenay (pp. 49-80). Bloomington: Indiana University Press.

Dundon, J. S. (1989). Bidayuh language and dialect. Sarawak Museum Journal, 30, 408-409.

Hyman, L. M. (1975). Phonology: Theory and analysis. New York: Holt, Rinehart \& Winston.

International Phonetic Association. (1999). Handbook of the International Phonetic Association: A Guide to the Use of the International Phonetic Alphabet. Cambridge: Cambridge University Press.

Jones, D. (1967). The phoneme: Its nature and use (3rd ed.). Cambridge: Cambridge University Press.

Ladefoged, P., \& Maddieson, I. (1996). The sounds of the world's languages. Oxford: Blackwell.

Ng, E. L., Chin, B., Yeo, A. W., \& Ranaivo-Malançon, B. (2010). Identification of closely-related indigenous languages: An orthographic approach. International Journal on Asian Language Processing, 20(2), 43-61.

Rensch, C. R., Rensch, C. M., Jonas, N., \& Robert, S. R. (2006). The Bidayuh language: yesterday, today and tomorrow. Kuching: Dayak Bidayuh National Association.

Trubetzkoy, N. S. (1969). Principles of phonology. (C. A. M. Baltaxe, Trans.). Berkeley: University of California Press.

Twaddell, W. F. (1935). On defining the phoneme. Baltimore: Waverly Press.

William, N. (1988). Daya Bidayuh-English dictionary. Kuching: Sarawak Literature Society.

Wolfram, W., \& Johnson, R. (1982). Phonological analysis: Focus on American English. Orlando: Harcourt, Brace, Jovanovich. 